\title{
New record of Charybdis goaensis (Decapoda: Brachyura: Portunidae) in Indonesia
}

\author{
Nisfa Hanim $^{1}$, Yusli Wardiatno ${ }^{2}$, Dyah Perwitasari ${ }^{1}$, Ali Suman ${ }^{4}$, and Achmad Farajallah ${ }^{1}$ \\ ${ }^{1}$ IPB U niversity, Faculty of M athematics and Natural Sciences, Department of Biology, Kampus IPB Dramaga, 16680 B ogor, \\ Indonesia \\ 2IPB U niversity, Faculty of Fisheries and M arine Sciences, Department of A quatic Resources M anagement, Kampus IPB D ramaga, \\ 16680 Bogor, Indonesia \\ ${ }^{3}$ Environmental Research Center, IPB U niversity, Kampus IPB Dramaga, 16680 Bogor, Indonesia \\ ${ }^{4}$ Research Center of Fisheries J akarta, M inistry of M arine and Fisheries Affair, 14430 Jalan Pasir Putih, A ncol Timur, North J akarta, \\ Indonesia
}

\begin{abstract}
The first report of Charybdis goaensis Padate, Rivonker, A nil, Sawant \& K rishnamurthy, 2010 was from Goa, India in 2010 year. Its occurrence in Indonesia is the second report in the world. The samples were harvested by a fisherman in Sibolga city and Natal district- $M$ andailing $N$ atal Regency, North Sumatera. We recorded three males and ten females of Charybdis goaensis, which consists of juveniles and ovigerous females. Both sampling locations are in one coastline in west coast Sumatera which faces directly to the Indian Ocean. We assumed that the dispersal of this species through the Indian Ocean is at their larval phase.
\end{abstract}

\section{Introduction}

Charybdis belongs to famili Portunidae which has a pair of paddle pad used for swimming. Family Portunidae has 404 species from 40 genera where Charybdis is one of them with the number of species about 63 [1]. Charybdis is characterized by its carapace which has anterior border more narrow than the posterior border and has six or seven anterolateral teeth [2]. Charybdis can be found in the shallow coastal environment, shallow nearshore water, and deep sea, while Charybdis goaensis which was reported from Goa, west coast India, was collected using trawling in the estuarine and offshore areas of Goa [3].

Study about genus Charybdis in Indonesia is still limited, even though the family of this species was reported spread broadly in a tropical Indo-West Pacific [4]. Marine ecosystem in west coast Sumatera is still categories as a good ecosystem which suitable for marine biota living, like crabs. This study aims to explore the biodiversity of Portunidae in Indonesia, especially with the new record category.

\section{Material and Methods}

This research was conducted in Sibolga City and Natal District, West Coast of North Sumatera on June 2018 and November 2018 respectively. The specimens were trapped in a fishing net belonging to a fisherman. The photograph of the specimens were captured using Canon Camera and were ilustrated using Huion tablet. The specimens were preserved in ethanol $70 \%$ for a day so that the tissue didn't break, and then substituted in ethanol $96 \%$ for depository. The specimens were deposited in Laboratory of Animals Biosystematic, Departement of Biology, IPB University. Identification was referring to Padate et al. [3], as the first describer of Charybdis goaensis. Information about the measure was available, Carapace Width (CW) and Carapace Length (CL). CW was measured from both the tip of the posterolateral tooth, and CL was measured from the indentation of median teeth until the posterior border of carapace using caliper.

\section{Result and Discussion}

Ordo Decapoda Latreile, 1802

Infraordo Brachyura Latreile, 1802

Famili Potunidae Rafinesque, 1815

Subfamili Thalamitinae Paul'son, 1875

Genus Charybdis De Haan, 1833

Charybdis goaensis (Padate, Rivonker, Anil, Sawant \&

Krishnamurthy, 2010)

\footnotetext{
* Corresponding author: achamadfarajallah@gmail.com
} 

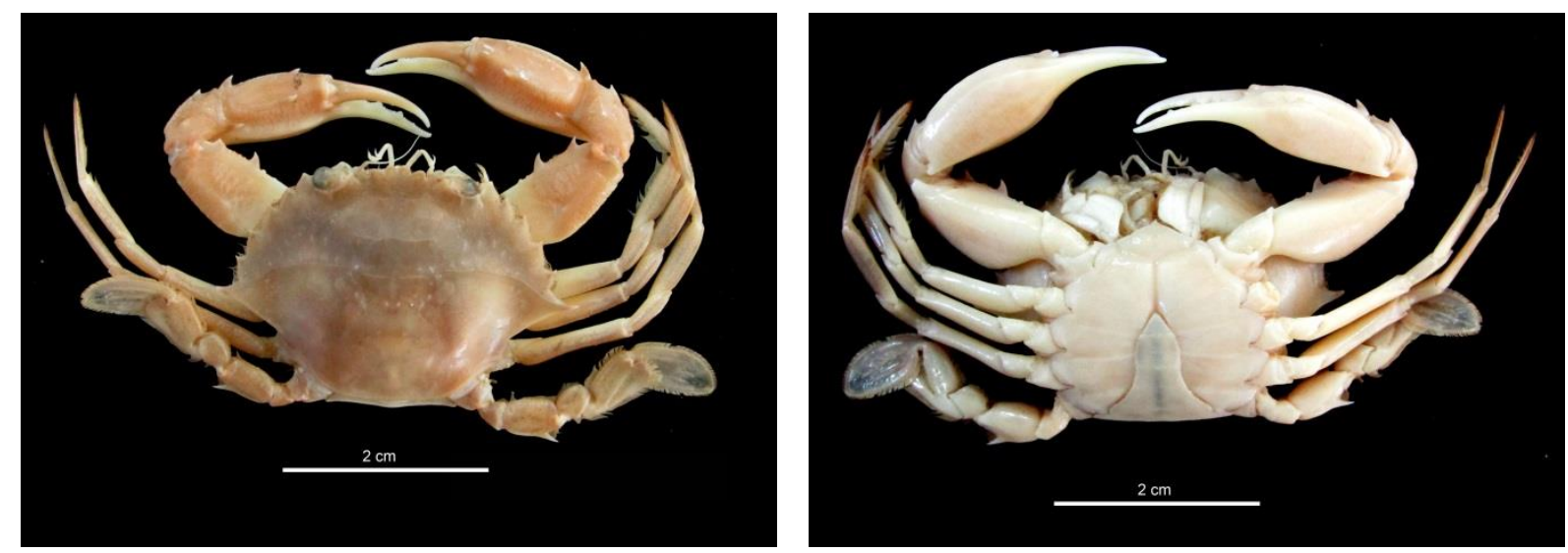

a

$\mathrm{b}$

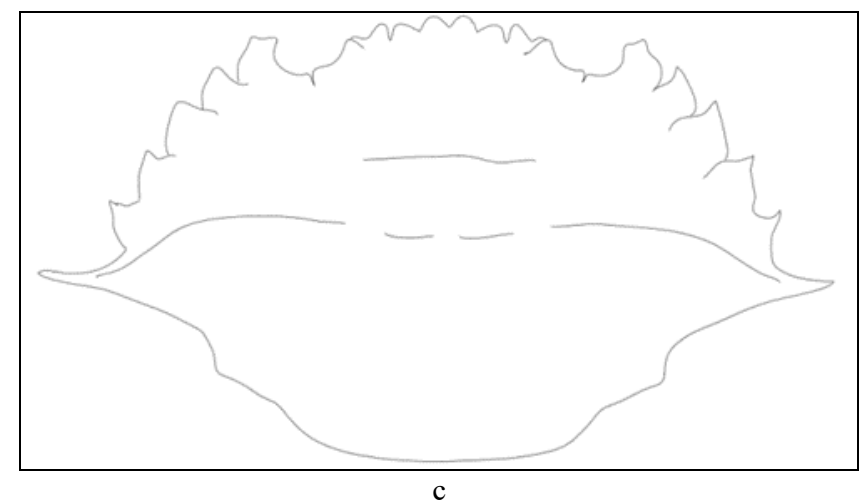

Fig. 1. Charybdis goaensis, adult male (CW $35.75 \mathrm{~mm}, \mathrm{CL} 22.80 \mathrm{~mm}$ ); (ventral) (a), dorsal (b), ilustration of carapace (c)

\subsection{Examined Materials}

Three males (CW $35.75 \mathrm{~mm}$, CL $22.80 \mathrm{~mm}$ ) Sibolga City, (CW 18.65 mm, CL 17. 80; CW 30 mm, CL 19,15 $\mathrm{mm}$ ) Natal District, six mature females (CW $32.20 \mathrm{~mm}$, CL 19.35; CW $38.85 \mathrm{~mm}$, CL $23.00 \mathrm{~mm}$; CW 33.70 mm, CL 20.20 mm; ) Sibolga City,(CW 29.90 mm, CL $17,75 \mathrm{~mm}$;CW $39.4 \mathrm{~mm}$, CL $24.25 \mathrm{~mm}$;CW $38.8 \mathrm{~mm}$, CL $23.1 \mathrm{~mm}$ ) Natal District, two ovigerous females (CW
$37.45 \mathrm{~mm}$, CL $25.65 \mathrm{~mm}$; CW $34.1 \mathrm{~mm}$, CL $22.4 \mathrm{~mm}$ ), two immature females (CW $24.1 \mathrm{~mm}$, CL $14.2 \mathrm{~mm}$; CW $27 \mathrm{~mm}$, CL $15.9 \mathrm{~mm}$ ), Natal District.

\subsection{Diagnosis}

This species has unique characters, i.e. two spines on merus of cheliped and three spines on its manus.

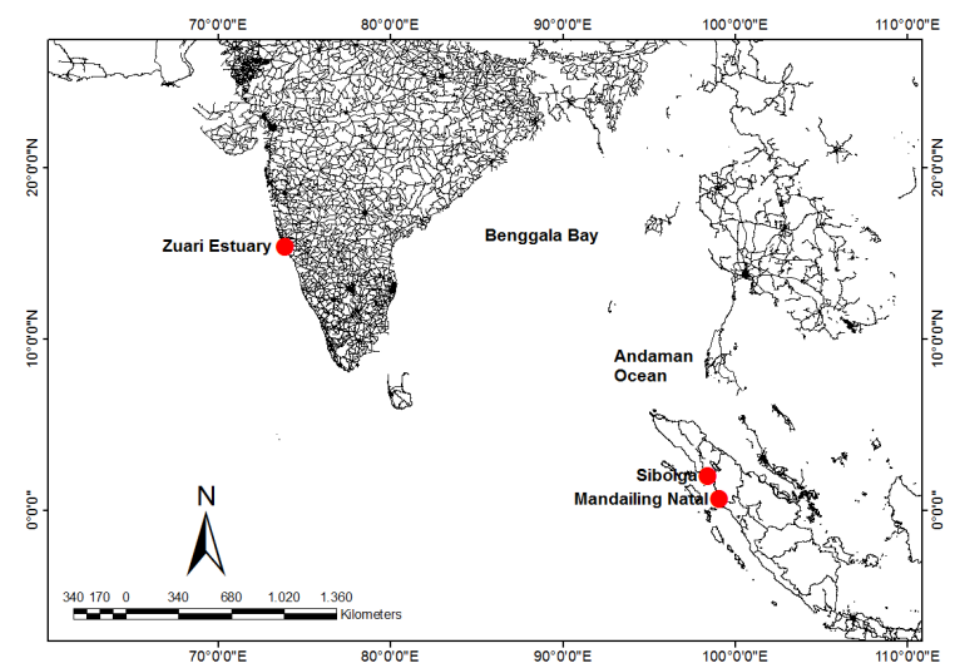

Fig. 2. Distribution map of Charybdis goaensis. Sibolga and Mandailing Natal are part of North Sumatera Province, Indonesia (this study). Zuari estuary is in Goa, India (previous study). 


\subsection{Description}

On the surface of the carapace, epibranchial ridge, metagastric ridge, and mesogastric ridge are visible. In the anterolateral carapace towards the frontal, there is like fine hair. The teeth in the anterolateral part have an arrangement similar to that of Charybdis philippinensis [5] where the size of the spines is increasingly pointed toward the posterior part. The size of the posterolateral teeth is twice as large as the size of the previous teeth. The front teeth are divided into six parts (not including the inner supraorbital lobe) with the submedian frontal tooth being the largest size. The anterior part of merus of the cheliped has two sharp spines, the anterior of carpus has one sharp spine with a relatively larger size than the other spines on the cheliped. The posterior of carpus has three smaller sharp spines, while menus has three sharp spines. At the posterior end of the merus of the swimming leg has one sharp spine.

Distribution: Goa, West Coast India [3]; West Coast Sumatera, Indonesia

Charybdis goaensis which were found in Goa, India [3], morphologically have smaller size compare to our specimens from West Coast of North Sumatera, both in male and female. The average of Carapace Width (CW) for males and females of Charybdis goaensis from Goa were $27,83 \mathrm{~mm}$ and $25.52 \mathrm{~mm}$ respectively, while our specimens have $28,13 \mathrm{~mm}$ in males and $33,55 \mathrm{~mm}$ in females.

Brachyura has a complex life cycle starting from planktonic larvae as well as benthic juveniles to adulthood [6]. The existence of this larval phase allows a wide distribution of Brachyura, mainly by the mediation of currents. In this case, the dispersal of Charybdis goaensis could be mediated by the Indian Ocean.

\section{Conclusion}

Charybdis was reported for the first time in Indonesia, namely Sibolga City and Natal District, West Coast of North Sumatera.

We would like to thank the Program Magister Menuju Doktor untuk Sarjana Unggul (PMDSU) Grant 2017 from the Ministry of Research, Technology, and Higher Education of the Republic of Indonesia for supporting our study.

\section{References}

1. K. Anger, The Biology of Decapod Crustacean Larvae, Crustacean Issues (Taylor \& Francis, United Kingdom, 2001)

2. P. K. L. Ng, D. Guinot, P. J. F. Davie, Raffles B Zool, 17, 1-286 (2008)

3. V.P. Padate, U.R. Chandrashekher, C.A.A, S.S Subhash, K. Venkat, Mar. Biol. Res., 6, 579-590 (2010) https://doi.org/10.1080/17451000903505608
4. G.C.B. Poore, Marine Decapod Crustacea of Southern Australia (Csiro Publishing, Australia, 2004)

5. M. Ward, Bull. Am. Mus. Nat. Hist., 1104, 1-15 (1941)

6. D. P. C. Wee, P. K. L. Ng, Raffles B Zool, 1-128 (1995) 